\title{
The Classification and Description of Speech Strategies of Communicators in Bilingual Situation
}

\author{
Nursulu Zhamalbekovna Shaimerdenova \\ Doctor of Philological sciences, Gumilyov Eurasian National University, Satpaeva Str. 7 \\ Astana, 010000, Republic of Kazakhstan; 777nursulu@mail.ru
}

\begin{abstract}
Ainagul Erbolatovna Ismagulova
Candidate of Philological sciences, Kokshetau State University after Sh.Ualikhanov, Abay Str.76 Kokshetau, 020000, Republic of Kazakhstan; ismainagul@rambler.ru
\end{abstract}

\begin{abstract}
Alma Karisovna Zhukenova
Candidate of Philological sciences, Kokshetau State University after Sh.Ualikhanov, Abay Str.76 Kokshetau, 020000, Republic of Kazakhstan; Zhukenalma@rambler.ru
\end{abstract}

\author{
Mainura Abiltaevna Buribaeva \\ Candidate of Philological sciences, Gumilyov Eurasian National University, Satpaeva Str. 7 \\ Astana, 010000, Republic of Kazakhstan; mainura_b@mail.ru

\section{Dinara Sarsembaevna Ryspayeva}

Candidate of Philological sciences, Kokshetau State University after Sh.Ualikhanov Abay Str.76, Kokshetau, 020000, Republic of Kazakhstan; goldensunrise@mail.ru

\section{Djemma Bulatovna Amanzholova}

Candidate of Philological sciences, Autonomous Educational Organization "Nazarbayev Intellectual School" Astana, 010000, Republic of Kazakhstan, 31 str,37; jemma.aman@jmail.com

\section{Marina Vasilievna Tavlui}

Candidate of Philological sciences, Kokshetau State University after Sh.Ualikhanov Abay Str.76, Kokshetau, 020000, Republic of Kazakhstan; marina-tavluy@mail.ru

Doi:10.5901/mjss.2016.v7n1s1p174

\section{Abstract}

The article is devoted to the actual problem of the modern linguistics - study of the peculiarities of perception and organization of language material by bilinguals. The aim of the investigation is to classify and describe speech strategies of communicators in the context of natural and artificial bilingual situation. The authors analyze speech and behavioral strategies of bilinguals, which they choose in this or that language or definite language units to describe certain situations and use of expressions according to the norms of a language and also conscious and unconscious use of code switching. The following methods of investigation were used in the article: observation, generalization, semantic and pragmatic interpretation that constitute a part of descriptive and analytical method. The results of the classification and description of speech strategies of communicators confirm that recording of bilinguals' language behavior is of a great interest for the modern language paradigm as it fully reflects the linguistic reality in natural and artificial bilingualism. Research perspectives lie in the further investigation of speech behavior of communicators of different ages and ethnic groups in various spheres: business, economy etc. and in polylingual community as well.

Keywords: bilingualism, speech strategy, code switching, communication act. 


\section{Introduction}

The development of linguistics in the $20^{\text {th }}$ century to some extent was defined by the changes of the leading theoretical objectives. In 1970-1980 linguists came to the conclusion that without regard to speech act participants - speaker (addressor) and listener (addressee), not knowing communicative situation it is impossible to describe the semantics of speaking adequately. The modern science considers a human being as an addressor and as an addressee in a close relation to linguistic and social reality, i.e. in a close connection with the way he lives and acts within the linguistics [Leontyev, 1974].

Linguistic of globalization epoch is characterized by a particular attention to considering language as means of communicative influence that acts in a social context and orientates at the study of speech communication, language behavior and speech behavior and also terms of communication which contribute to successful achievement of the set goals. Study of language/speech - world - subject is of importance in a pragmatic view.

The novelty of investigation of communicators' speech strategies in the context of natural and artificial bilingualism is defined by the fact that such investigations relate to the problem of anthropocentric and communicative and functional paradigms of linguistic knowledge and put into practice a complex approach to investigation of different means of achieving effective communication in bilingual situations. In this regard, there is a necessity to describe systematically and to classify the means of performing purposeful actions with the help of linguistic means and code switching in bilingual situation.

The object of the research are speech strategies in a bilingual communicative situation, subject of the research peculiarities of decisions and acts of communicators which were planed beforehand or appeared as a result of a spontaneous dialogue and aim at achieving communicative goal in a bilingual situation. The research was conducted using descriptive-analytical method and its main components: observation, generalization, semantic and pragmatic interpretation. As sources for language material recordings of oral speech of students of KSU named after Sh.Ualikhanov and dialogues of the citizens of the city of Kokshetau were used.

As a result of the investigation of speech strategies of communicators in natural and artificial bilingualism credible factual evidence was obtained, classification of speech strategies in bilingual situation was specified, means of using defined communicative acts in the Kazakh, Russian and English languages were defined, communicative pragmatic potential of speech strategies in natural and artificial bilingualism was specified.

The results of analyses of the obtained material prove that speech strategies which present a complex of steps realized in the communicative act planned by the speaker beforehand and aimed at the achievement of the communicative goal, foster effective organization of interaction and influence upon the addressee, are characterized by semantic and pragmatic grammatical peculiarities and level of human cognitions. Thereby they have own cognitive plans which are defined by different cognitive dimensions in various spheres, for example in educational and every day spheres.

Semantic, pragmatic and dialogue types of speech strategies are used in natural and artificial bilingualism situations, conscious and unconscious code switching also takes place. Thereby there is a mixing of languages: the usage of informants in one language with elements of the other language (words, phrases and bigger units). Linguistic manipulation as a kind of cognitive activity of an individual is implemented in different situations in most cases latently but it appears in the language behavior of the communicant.

\section{Literature Review}

Linguistics in Kazakhstan as well as abroad from the middle of $20^{\text {th }}$ century saw major works which fully represent the results of investigation of speech influence in communication sphere. Thereby particular attention is paid to certain aspects of the process of a person's speech control which are investigated by linguists, psychologists and representatives of allied disciplines that aim at human speaking.

According to scientists linguistic manipulation means goal-oriented, motive determined oral communication. Phenomenon of linguistic manipulation is mainly connected with the aim of the speaker - the subject of linguistic manipulation. The aim of the subject of linguistic manipulation is to control both physical and intellectual activity of the interlocutor. Investigation made by Baranov and Parshin [1986], Karasik [1992], Fedorova [1991] and others prove that it is the speech of the partner that induces to begin, to change, to stop any activity, influence on taking decisions or visions of the world.

Thus, analysis of linguistic manipulation is conducted from the perspective of one communicant - subject of linguistic manipulation, and the other communicant is the object of influence. According to Lakoff [1982], discourse can be 
considered persuasive only when it is unequal i.e. when one of the communicants attempts to influence consciously.

In addition, another point of view pulls linguistic manipulation and linguistic exchange together. The essence of this approach is the concept of Burke's "identification" [1970; 1986]. It means that reality is not "present" in the process of communication: we receive it in the form, which is defined with the help of "symbols" - language as a semantic system. Characteristics, description of this or that situation include choice of symbols, and this choice is not neutral.

Symbolic exchange in the process of communication satisfies and identifies our visions of world. This process (symbolic exchange) includes identification of speaker and audience: core values and ideas of the speaker correspond to the ideas and directives of the audience, one group modifies the other. Thus, interinfluence effect can be observed, as correction of both communicants world models is implemented [Zarefsky, 1989].

At the turn of 20-21 centuries pragmalinguistic investigation of fundamental categories: speaker, listener, speech act, intention (illocutionary force), speech situation, strategies and tactics of speech behavior became actual. Due to the works of Arutyunova [1990], Wierzbicka [1997], Van Dijk [1989], Vinogradov [1980], Vinokur[1993], Lakoff [1973, 1982], Leontyev [1974], Ostin [1986], Paducheva [1982], Searle [1986], Sukhikh [1986], Jacobson [1985] and others the abovementioned terms and notions entered science and have generally accepted definitions.

The authors of the article share the opinion that natural bilingualism means knowledge and application of two languages as a consequence of direct influence upon the speakers. Artificial bilingualism means knowledge and application of two languages as a consequence of intended and purposefully provided facilities for learning the second language and other languages. [Suleimenova, Shaimerdenova and others, 2007].

The generally accepted term for "bilingualism" is a human's ability to use two language systems by turn for communication. Due to bilingualism, active intercultural communication develops and human civilization evolutes. The problem of bilingualism goes far beyond the theory of speech activity and is closely connected with the comparative typology of languages, problems of origin and development of different languages, study of language universal forms, unique forms etc.

There is a great variety of bilingualism types acknowledged by modern sociolinguistics: from passive bilingualism, when an individual understands speech in a foreign language, but does not speak it, to the mastery use of languages. Low level of knowledge and usage of the second language is mostly determined by a narrow sphere of its usage. Bilinguals usually have in equal status of languages, in most cases it is connected with extralinguistic factors. Language, the sphere of usage of which is broader has a "linguistic pressure" on individuals, who prefer to use it in most linguistic situations. The existing extralinguistic factors create a "social pressure" on bilinguals, forcing them to give prefernce to one language. "Linguistic" and "social" pressure always depends on external conditions of using language and can vary in different situations. The linguistic situation in Kazakhstan deals with natural and artificial bilingualism. It is mostly seen in educational and everyday spheres.

\section{Methods and Results}

According to Karlinsky [1990] the characteristic of a bilingual is his/her belonging to three linguistic communities: primary (monolinguals, speakers of L1), secondary (monolinguals, speakers of L2) and bilingual (bilinguals, speakers of L1 and L2). A bilingual can use either L1 or L2 in different situations for communicating, he/she can also demonstrate bilingual behavior with interference elements, intercalation and code switching. First two notion mix, although there are big differences among them.Interference means influence of $L 1$ on $L 2$, intercalation is penetration of $L 2$ elements into speech in L1. There is inventory and phrasal intercalation. Inventory intercalation is penetration of separate words from L2 into L1 and is divided into nomenclative and redundant. Phrasal intercalation means penetration of solid units from L2 into L1. This kind of intercalation has many types: from binary collocation to the whole expression as apart of compound sentence. Phrase intercalation has the following elements: binar insertions («Давай пойдём в кино (together with Olga)»),speech loans means use of foreign word collocation that can partly or fully be filled with lexical material in L1, foreign epenthesis - epenthetic sentence structured according to the norms of L2 («Ты знаешь (what his wife said), когда Николаевы пришли к нам на свадьбу?»),quotations («Я хочу (to be with you forever) и никогда не расставаться»). This kind of intercalation is much alike code switching and requires gradual delimitation.

Semantic type of strategy is also of a great interest. Strategy of subordination and strategy of discreditation show it. Persuasion influences not mind and logic but feelings and emotions of the addressee. A person being persuaded is usually dependent on the object. According to the scheme of describing speech tactics Issers [2008] highlights qualities of persuasion and conditions of successful implementation of this tactics. The following qualities refer to them: information about the forecoming communicative event, position in the coming dialogue, terms for successful speech tactics, perlocutionary effects, conversational turns and language markers. 
According to the data obtained with the help of "participant observation" method models of argumentation, based on appeal to feelings, relations between speaker and listener, qualities of the partner, his/her authority, categories of "harm" and "benefit" are the most productive ones.

Card files, composed according to the results of processing the data obtained from the informants there are examples of using persuasion tactics. One of them shows a conversation between mother and child. The woman is a teacher of English (M) and her son is a student of 5 Grade in gymnasium who learns English (C). Son tries to persuade his Mom to buy him a dog. C: «Мама, давай заведём собаку». М: «Никаких собак! От них одни проблемы! Учебный год начинается. Кто с ней будет гулять? Её ещё нужно воспитывать». С: «Я буду её вьгуливать, буду вставать пораньше, буду учиться в этом году на одни пятёрки». М: «Я знаю, как ты «встаёшь пораньше», так что гулять с ней придётся мне». C: «If only you saw, how funny they are! Their ears are so nice, their eyes are so pretty, their paws are so small. Do you remember your favorite film: "White Bim with a Black Ear»? Do you remember that puppy?». M: «Do you know how much they eat?». C: «Hy, вы ведь с nапой зарабатываeme достаточно, чтобы прокормить одну маленькую собачку. Вы цельми днями на работе и вечерами задерживаетесь. Мне так скучно одному. If I have a dog, I shall get only excellent marks». М: «Ты уже придумал, как мы её назовём?». During persuasion the subject places himself in a position dependent from the partner, because he cannot speak equal to her, so he serves as a pleader. The specifics of tactics is that the speaker has no right to give orders. Persuasion is pressure upon the adressee, manipulation implemented by addressor with force.

The communication linkages are of interest when they include an argumentative component. The peculiarity lies in the fact that each linkage has a positive and a negative realization. The communicative linkage «an appeal to the feelings, relations» contains its positive realization («Ты же меня любишь...», «Сделай это ради меня...», «Мы же друзья...») and the negative one: («Если бы ты меня любил...», «Я к тебе со всей душой, а ты...», «Ты мне друг или кто?»). The cognitive condition for the given linkage is the understanding of the feelings of communicants to each other, the feelings which both sides consider valuable. The first three models confirm these applications, the subsequent ones question them. The examples of the second group are united by the fact that their primary function is reproach with the cognitive conditions basis in unjustified expectations. It lets us to apply the «negative» models to the indirect implementation of speech persuasion tactics. In the study of a bilingual situation the given model is represented by the markers fixing relations «the speaker - the addressee». Two students of the English department are sitting at the computer, one of them is typing on the computer (D1), the other is dictating to her (D2). D2: «Зарина, посмотри, половину мы уже сделали, осталось-то совсем немного. We are friends forever. You know the proverb: «A friend in need is a friend indeed». You are not going to leave me alone here. I shall not cope with it alone». The subject persuading the listener to reprint the text uses the argument defined as an appeal to the relations with the positive implementation: «Мы же друзья. Друг познаётся в беде. Ты же не оставишь меня одну за компьютером. Я не справлюсь одна». We can observe the transition to the confidential conversation by the code switch from the RL to the EL.

The explored material has shown that the speech of informants in a bilingual situation set some patterns in the sequence and correlations of communication linkages. The sequence of communication linkages is not strictly determined; it entirely depends on the reaction of a partner in the process of communication. The response is determined by the entire complex of cognitive, psychological and communicative parameters characterizing the situation of communication. Thus, the aim of the speaker is to change the parameters «into his/her favor» with the help of several communication linkages.

In the context of the study of pragmatic strategies the emotionally tuning tactics - compliment - has been analyzed. The implementation of the strategic objectives depends on the communicative context of the verbal communication. One of its components is the type of relationships between the communicants. For all the variety you can find a number of communication concepts that characterize the relationships between the participants of the communicative act. These should include the distance between the communicants, which is a continuum embodying various relationships (sympathy, love, indifference, hostility). Such psychological characteristics are not permanent, as in the process of communication they are adjusted. There are special techniques of «distance control»: the tactics of «convergence» and the tactics of «alienation». It has been found that speakers use verbal signals of «convergence» to direct the interpersonal distance. Such signals include direct recognition of sympathy, etiquette formulas, pronoun indicators of the partner's inclusion into the sphere of interests of the speaker (plural personal pronouns), signals of emphatic listening, etc. [Mottet, Richmond, 1998]. The repertoire of tactics implementing the verbal strategy of «distance control» includes the tactics of compliment.

People do not use compliments in a tragic situation, an emergency, a serious controversy, or a conflict, although a good compliment can defuse the situation. The success of the speech tactics of compliment is closely related to the 
conditions of communication. The author of the compliment has a better chance of success in a relaxed atmosphere of conversation. The compliment is mainly used in the spheres of informal communication and conversation. We consider the tactics of compliment mainly on the material of lively conversation in a bilingual situation. The main function of a sincere compliment is to establish contacts and maintain good relations. The strategic objective of the speaker is to elicit sympathy, to win the interlocutor. In this regard, the distinctive feature of a compliment is an open demonstration of intention of the speaker, that is, his/her desire to say something pleasant to the companion. For example, the statement about a new thing of your friend: "Oh, you have bought a lot of new things». We believe that this statement is difficult to consider a compliment, as the intention is not clearly expressed.

Despite the fact that the tactics of compliment and the tactics of praise have a common communicative purpose closely related to the positive assessments, they have significant differences. The main difference lies in the fact that the main purpose of praise is a positive assessment, and the purpose of a compliment is a message of good feelings and favor. It can be observed in the example where the speaker deliberately uses metatext indicators of the speech tactics: "You look great and it is absolutely not a compliment» - «Вы прекрасно выглядите. И это абсолютно не комплимент». In this case, the emphasis is on the fact that a positive assessment of the appearance is motivated not only by maintaining good relations but by the objective data. The discrepancy between the communication goals of the tactics of compliment and praise leads to the differences in the perlocutionary effect. An indicator of success of the tactics of praise is the adoption of the evaluation, an indicator of its failure is the rejection.

The conversation is between two English teachers after the event of the faculty - «Halloween», which is celebrated on the first of November.

Tatyana Vladimirovna: Cnacuбo, что организовали такой весёлый праздник для всех студентов нашего фракультета. You were the most active teacher among all of us. Well done!

Elena Valeryevna: We must thank all my students. All thanks to them.

The indicator of the failure of the tactics of «praise» is the rejection of Elena Valeryevna: We must thank all my students. All thanks to them - Мы должны благодарить всех моих студентов. Это их заслуга.

As for the compliment, the recipient's disagreement with the speaker does not mean the failure of tactics.

The conversation is between the students of the English department of the university after the event: «Beauty Contest».

Aigerim: «Зарина, не переживай. Второе место тоже хорошо. All the rest cannot be compared with you. They are ugly». Zarina: "Don't say so». Aigerim: «Anyhow, you are the most beautiful girl in our faculty». Zarina: "Thank you».

The speaker (Aigerim) says a compliment to the addressee (Zarina) to support her. The speaker expresses her disagreement, but, despite this, the compliment is adopted.

The differences between a compliment and praise are found in the propositional content. Praise involves assessing the qualities, knowledge, skills of the addressee. To get the praise, it is necessary to do something, to express yourself in a positive way, such as: "You can speak English fluently» - «Ты умеешь бегло говорить по-английски». Praise is an assessment of achievements. Compliment is not limited in this regard, because it is possible to make a compliment noting blue eyes, skin color, etc., but you should make a compliment for the «blue-eyedness». Compliment refers to the ritual speech acts, so the first condition for the success of a compliment is knowledge of the relevant rules of verbal behavior. The ritual is based on the principle of «politeness»: compliments are easily accepted from strangers, and even from those who do not cause our sympathy. This rule does not apply only when the speaker intrudes into the personal space of the addressee, violating generally accepted norms.

Another condition is the specificity of a message in the verbal tactics of compliment. A sign standing out as a positive assessment must be directly relevant to the recipient, and to be included into the «scope of the recipient» [Shmeleva, 1995]. Otherwise, the author is expected to have a communicative failure.

The conversation is between two students of the English department.

Farkhat: «Оксана, у тебя новое платье?». Oksana: «Да, вчера купила». Farkhat: «What a nice dress. It matches your eyes». Oksana: "By the way, my eyes are grey». The speaker (Farkhat) makes the compliment to the recipient (Oksana): «What a nice dress. It matches your eyes perfectly» - «Какое красивое платье. Как раз под ивет глаз». However, he has a communicative failure as the compliment is not relevant to the recipient: «By the way, my eyes are grey» - «Глаза у меня серые, между прочим».

The tactics compliment does not depend on the preliminary positions of the parties, because the conditions for uttering compliments do not impose restrictive framework for the communicative situations where a compliment is possible. The main perlocutionary effect that the speaker waits from a compliment is defined as the acceptance of the compliment. An indicator can be verbal and nonverbal reactions. The verbal response is in the semantic field of gratitude and agreement with the assessment of the speaker or in the field of etiquette «disagreement». A reciprocal compliment 
can be considered as a signal of success of the tactics. The conversation is between the curator of the group (C) and the student (S). C: «Сергей, преподаватель философии говорит, что ты пассивен на его семинарах. To tell the truth I am really surprised. I considered you to be the most active student in my group». S: "I am active only in your classes». In the given situation the speaker $(\mathrm{C})$ makes the compliment to the student to make him more active at the seminars of Philosophy: "To tell the truth I am really surprised. I considered you to be the most active student in my group» «Честно говоря, я очень удивлена. Я считала тебя самым активным студентом в своей груnпе». The listener (S) makes the reciprocal compliment thus showing that English lessons are more interesting for him rather than Philosophy: «I am active only in your classes» - «Я активно работаю только на ваших занятиях».

According to the presence of illocutionary forcing, compliments are divided into initiative and forced. According to the way of expression of an intention they can be direct and indirect. In a bilingual situation there are different compliments: a «simple» compliment highlighting the external, moral, intellectual background of the recipient («What a gifted student!» - «Какой способный студент!»), a compliment «from a thing - to a person», when the assessment of an item relating to the listener means positive assessment of the listener himself/herself («You are irresistible in red» «Ты неотразима в красном»), a compliment - comparison («Skirts suit уои» - «Юбки идут вам (брюки нет)», «Үои are like Schwartseneger» - «Ты, как Шварценегер»), a compliment by the «stranger's mouth» when the authorship of the compliment is attributed to a third party to create the illusion of an objective assessment, and also in cases where the speaker does not want an open demonstration of his/her feelings ("Il heard that you speak three foreign languages perfectly well» - «Я слышал, что вы в совершенстве владеeте тремя иностранными языками»). The list of complementary communication linkages is open and can be significantly expanded.

\section{Discussion}

Observing the interaction of students in a bilingual situation indicates that informants actively use their knowledge in the classroom and in other communicative situations. Often, outside the classroom students use the phrases of the target language, which are naturally included into the language system, and are reflected in the speech-behavioral strategies and tactics. The bilinguals using the second language in various communicative situations and achieving mutual understanding are of great interest.

Bilingualism creates the situation of active mastering the both languages, characterized by the code switching in a variety of communicative acts. Consequently, a bilingual is an individual speaking both languages to an extent that allows him/her to use both languages in communication. Considering bilinguals as bearers of active bilingualism, we can assume that the level of language skills may be different. Speech behavior of a bilingual is usually an individual choice of a language or a certain linguistic units to describe the situation and the appropriate use of statements according to the standards, as well as conscious and unconscious use of code switching.

\section{Conclusion}

Speech strategy is a set of implemented linkages in the communicative process. The choice of a strategy and tactics of speech is impossible without taking into account the fact, whether the conditions of communication correspond with the successful implementation of the planned speech or not. Consequently, the category of «conditions for success» can be used in describing the speech strategies and tactics.

General knowledge of the communicative situation, the relevant speech act, the interlocutor is the main parameters determining the selection of the strategy and tactics of speech and communication linkages. The speech strategy controls the optimal solution of problems in a flexible and locally controlled manner. The speech strategy is a plan for comprehensive impact that the speaker performs for «manipulation» of the partner. The speech strategy is based on interpretation. Interpretation is required for operations on the knowledge of a partner, his/her categories of value, emotions and will. According to the functional point of view, there are main (semantic, cognitive) and secondary strategies. The main strategies include those associated with the impact on the recipient, his/her model of the world, system of values, physical and intellectual behavior. Secondary strategies contribute to the effective organization of a dialog interaction, the optimum impact on the recipient. Methods and techniques that individually or in combination lead to the solution of a super-task, are constituents of the speech tactics, they are called communicative linkages. Communicative linkages are carried out under the supervision of the strategy and tactics.

It is natural for a bilingual to speak the language dominating his/her life. In this case, the bilingual can select two lines of verbal behavior in the process of communication with other bilinguals: to speak only the dominant language or to speak mainly the dominant language using the second language in some situations. Such verbal behavior of a bilingual is 
considered to be natural and typical. The reasons for the change of languages in the communication are of a different nature. Formation of the types of verbal behavior of bilinguals depends on a complex and subtle interaction of situational, social and demographic factors.

The prospect of the given study is to explore further the verbal behavior of communicants of different age and ethnic groups in various spheres of life (for example, in business and economics), and in poly-lingual Kazakhstan society as a whole.

\section{References}

Leontiev A. (1974). Speech activity // Fundamentals of the theory of speech activity. Moscow: Science.

Baranov A. Parshin, P. (1986). Language arrangements of variation interpretation of reality as a means of influencing the consciousness // The role of language in the mass media. Moscow.

Blakar R. (1987). Language as an instrument of social power // Language and modeling of social interaction. Moscow: Progress.

Karasik B. (1992). The social status of a person in the linguistic aspect // "I", "subject", "individual" in the paradigms of modern linguistics: Coll. of scientific and analytical reviews. Moscow.

Fedorova L. (1991). Typology of speech influence and its place in the structure of communication // Questions of linguistics. Moscow.

Lakoff R. (1973). The logic of politeness, or Minding your P's and Q's. Papers from the 9-th Regional Meeting of the Chicago Linguistics Society.

Lakoff R. (1982). Persuasive discourse and ordinary conversation, with examples of advertising. In Tannen, D. (Ed.) Analysing Discourse: text and Talk. Georgetown University Press.

Burke, K. (1970). A grammar of motives. Berkeley: University of California Press.

Burke, K. (1986). Language as symbolic action. Berkeley: University of California Press.

Zarefsky, D. (1989). The state of the art in Public Address Scholarship. In Text in Context: Critical dialogues on significant episodes in America political rhetoric. HermagorasPress.

Arutyunova N. (1990). The phenomenon of the second replica, or the benefits of the dispute // Logical analysis of language. The inconsistency and deviance of a text. Vol. 3. Moscow.

Wierzbicka A. (1997). Speech genres // Genres speech. Saratov.

Van Dijk T. (1989). Language, cognition, communication. Moscow: Progress.

Vinogradov V. (1980). Selected works. On the language of fiction. Moscow: Science.

Grice, H. (1985). Logic and speech communication // New in foreign linguistics. Vol. 16. Moscow.

Issers, O., Kuzmin, N. (1997). Etiquette and anti-etiquette as lingual-didactic problem // RossicaOstraviensca-97: linguarossicain sphaeramercaturae // Ostrava.

Issers, O. (2008). Communicative strategy and tactics of the Russian language. Moscow. LCI Publisher.

Austin, J. (1986). Word as an action // New in foreign linguistics. Vol. 17. Moscow.

Paducheva, E. (1982). Subject of Language Communication in fairy tales by Carroll // Semiotics and Informatics. Vol. 18. Moscow.

Searle, J. (1986). What is a speech act // New in foreign linguistics. Vol. XVII. Moscow.

Sukhikh, S. (1986). Speech interaction and strategies // linguistic communication and its unities. Kalinin.

Jacobson, R. (1985). Selected Works. Moscow: Progress.

Suleimenova, E., Shaimerdenova, N., etc. (2007). Dictionary of sociolinguistic terms. Almaty: Kazakh University.

Karlinsky, A. (1990). Fundamentals of the theory of language interaction. Alma-Ata: Galim.

Mottet, T., Richmond, V. (1998). An inductive analysis of verbal immediacy: Alternative conceptualization of relation verbal approach / avoidance strategies // Communication Quarterly. Vol. 46.

Shmeleva, T. (1995). Speech genres: the experience of philological understanding // Collegium. №1-2. Kiev. 